Article

\title{
Vegetation Change and Its Response to Climate Change between 2000 and 2016 in Marshes of the Songnen Plain, Northeast China
}

\author{
Yanji Wang, Xiangjin Shen *, Ming Jiang and Xianguo Lu \\ Northeast Institute of Geography and Agroecology, Chinese Academy of Sciences, Changchun, \\ Jilin 130102, China; wangyanji@iga.ac.cn (Y.W.); jiangm@iga.ac.cn (M.J.); luxg@iga.ac.cn (X.L.) \\ * Correspondence: shenxiangjin@iga.ac.cn
}

Received: 12 March 2020; Accepted: 23 April 2020; Published: 27 April 2020

check for updates

\begin{abstract}
Songnen Plain is a representative semi-arid marshland in China. The Songnen Plain marshes have undergone obvious loss during the past decades. In order to protect and restore wetland vegetation, it is urgent to investigate the vegetation change and its response to climate change in the Songnen Plain marshes. Based on the normalized difference vegetation index (NDVI) and climate data, we investigated the spatiotemporal change of vegetation and its relationship with temperature and precipitation in the Songnen Plain marshes. During 2000-2016, the growing season mean NDVI of the Songnen Plain marshes significantly $(p<0.01)$ increased at a rate of $0.06 /$ decade. For the climate change effects on vegetation, the growing season precipitation had a significant positive effect on the growing season NDVI of marshes. In addition, this study first found asymmetric effects of daytime maximum temperature $\left(T_{\max }\right)$ and nighttime minimum temperature $\left(T_{\min }\right)$ on NDVI of the Songnen Plain marshes: The growing season NDVI correlated negatively with $T_{\max }$ but positively with $T_{\min }$. Considering the global asymmetric warming of $T_{\max }$ and $T_{\min }$, more attention should be paid to these asymmetric effects of $\mathrm{T}_{\max }$ and $\mathrm{T}_{\min }$ on the vegetation of marshes.
\end{abstract}

Keywords: NDVI; marshes; vegetation; climate change; Songnen Plain

\section{Introduction}

Marshes are an important type of wetland ecosystem worldwide, and recent research suggests that marshes may have an important role in the global carbon cycle [1-3]. Due to extensive distribution, marshes may affect the global climate through biogeochemical (carbon uptake and releases) and biophysical (physical properties of the land surface) processes [2]. As a key component of wetland, vegetation serves as a natural interface linking together soil cycle, water cycle, and atmosphere cycle tightly [4,5]. Marsh vegetation plays an important role in maintaining marsh functions (e.g., wildlife habitat, biodiversity protection, water conservation, carbon sequestration) [6]. For example, marsh vegetation species such as Triarrhena spp. and Phragmites spp. can provide habitat and food for wintering migratory birds [7]. The structure and composition of marsh vegetation can have significant effects on biodiversity and carbon burial of the marsh ecosystem under a rapidly changing climate [8,9]. Due to the effects of human interference and climate change, global marshes are facing degradation and loss [2]. Under the background of global climate change, understanding the response of marsh vegetation to climate change can contribute to accurately predict future vegetation changes and thus provide scientific instructions for wetland conservation and restoration $[10,11]$. Because climate change has significant effects on vegetation in the world, exploring the impacts of climate change on vegetation has become a hot topic of current global change research $[12,13]$. It is reported that climate change, including changes in temperature and precipitation regimes, can have significant effects on wetland vegetation on 
global and regional scales [14]. For example, previous study found that the distribution of vegetation in tidal freshwater wetlands in the Patuxent River estuary of Maryland is mainly determined by flooding related to increasing precipitation [15]. In some cold mountain regions, however, the temperature is thought to have a greater impact on the growth of wetland vegetation than precipitation [16]. In the southeastern United States, climate change is reported to result in an expansion of black mangroves at the expense of some salt marsh vegetation [17]. In temperate climate regions, warming temperatures can lead to mangrove forest expansion and salt marsh ecosystems expense [18,19]. By contrast, some studies found a positive relationship between precipitation and vegetation abundance in tidal saline wetlands $[20,21]$. Studies focused on the mangrove-marsh ecotone in North America and the mangrove transition zones in New Zealand and eastern Australia have found that temperature regimes can have a large impact on tidal saline vegetation aboveground biomass and canopy height [17,22-24]. Although many studies have analyzed the responses of vegetation to climate change in different regions of the world, few works focused on the responses of marsh vegetation to climate change $[25,26]$. Compared with other ecosystems, the marsh ecosystem has distinctive environmental conditions, which may result in distinct responses of vegetation to climate change [27]. Under the background of the global climate change, investigating the effects of climate change on marsh vegetation is crucial to further understand the relationships between climate change and vegetation on a global level.

Songnen Plain of China is a representative semi-arid region, which has a large area of marshes [28]. The climate in Songnen Plain is semi-arid, and vegetation in this region is very sensitive to climate change [29]. Many studies have investigated the responses of vegetation to climate change in the Songnen Plain, but most of them focused on the vegetation of the grassland ecosystem [30,31]. Shen et al. (2019) analyzed the impacts of temperature and precipitation on the vegetation of marshes in Northeast China, but they did not compare the seasonal responses of vegetation to temperature and precipitation changes. Due to climatic fluctuations and complicated physiological responses of plants to growth environments, the effects of climate change on vegetation are usually distinct in different seasons [32-34]. Therefore, the seasonal responses of vegetation in the Songnen Plain marshes to temperature and precipitation change are needed to further clarify. During the past decades, marshes in the Songnen Plain have undergone obvious loss and fragmentation [10,35]. In order to protect the ecological environment in the Songnen Plain of China, the Chinese government is taking massive action to protect and restore degraded wetlands in the Songnen Plain [36]. Investigating the vegetation change and its response to climate change in marshes of the Songnen Plain is important to provide valuable implications for the protection and restoration of wetland vegetation in this region. Based on daily maximum temperature $\left(\mathrm{T}_{\max }\right)$ and minimum temperature $\left(\mathrm{T}_{\min }\right)$ data, previous studies found asymmetric warming of global surface air temperatures: Nighttime minimum temperature increased faster than the daytime maximum temperature during the past decades [37,38]. Additionally, this asymmetric warming pattern would be more likely during day and night, instead of symmetric one $[37,39]$. It is interesting that some studies found asymmetric (i.e., different) effects of daytime and night-time temperatures on vegetation growth in the semi-arid region of China [37,40]. Shen et al. (2015) found that the night-time temperature had a positive effect, but the daytime temperature had a negative effect on the growth of temperate grasslands in China. It may be because warm daytime temperature could reduce water efficiency by enhancing evaporation, while enhancing leaf respiration caused by night-time warming may promote photosynthesis in the next day [37,40]. At present, it is still unclear whether there are asymmetric daytime and night-time temperatures on the growth of marsh vegetation in this region. Understanding the responses of marsh vegetation to day and night temperature can contribute to further explain the effects of asymmetric warming on ecosystem vegetation. In order to accurately predict future changes in the vegetation of Songnen Plain marshes, it is necessary to explore the separate effects of daytime and night-time temperatures on the growth of marsh vegetation in the Songnen Plain.

By using the normalized difference vegetation index (NDVI) data, this study analyzed the temporal and spatial changes of vegetation in the Songnen Plain marshes. Based on the climate data from 2000 to 
2016, the relationships of the growing season NDVI with temperatures (including mean temperature, maximum temperature, and minimum temperature, referred to as $T_{\operatorname{mean}}, \mathrm{T}_{\max }$, and $\mathrm{T}_{\min }$ hereafter) and precipitation were analyzed to explore the possible effects of climate change on marsh vegetation. In addition, we compared the responses of vegetation to temperature and precipitation changes in different months of the growing season. Based on previous related studies discussed above, we predict that marsh vegetation growth during 2000-2016 has been affected by changes in precipitation and temperature. The major scientific questions that this study seeks to address are: (1) Is the vegetation of marsh in Songnen Plain more affected by precipitation or temperature? (2) whether the maximum temperature and minimum temperature also have the asymmetric effects on the vegetation of marsh in Songnen Plain? As marshes in the Songnen Plain are a representative semi-arid marsh wetland in the world, this study can be expected to provide useful information about the effects of climate change on wetland vegetation in semi-arid regions, which will have implications for biodiversity, carbon cycling, and sustainability of wetland ecosystems. More specifically, it can contribute to the understanding of how temperature and precipitation regimes in recent years have affected wetland vegetation, and how the changes of these regimes associated with climate change could affect wetland functions in the future, a largely unresolved question in current wetland studies.

\section{Materials and Methods}

\subsection{Study Area}

The Songnen Plain is located in the central part of Northeast China, lying between $42^{\circ} 19^{\prime} \mathrm{N}-49^{\circ} 12^{\prime} \mathrm{N}$ and $121^{\circ} 36^{\prime} \mathrm{E}-126^{\circ} 36^{\prime} \mathrm{E}$. This study area includes 35 counties of Heilongjiang province and 20 counties of Jilin province, with a total area of $11.51 \times 10^{4} \mathrm{~km}^{2}$ (Figure 1). The climate in the Songnen Plain is a semi-humid climate. The annual average temperature ranges from $4{ }^{\circ} \mathrm{C}$ to $6{ }^{\circ} \mathrm{C}$, and total precipitation is from 350 to $650 \mathrm{~mm}, 80 \%$ of which is concentrated between May and September. Averaged over the period of 2000 to 2016 , the mean annual temperature is about $4.61^{\circ} \mathrm{C}$ and decreases from south to north. The average annual precipitation is about $475.92 \mathrm{~mm}$ in the Songnen Plain, increasing gradually from west to east (Figure 2). The soil in the Songnen Plain mainly includes black soil, chernozem, meadow soil, Solonetz, Solonchak, and aeolian soil [18]. Natural vegetation in the study area is dominated by temperate steppe and temperate meadow. The Songnen Plain has a large area of marshes, which is an important distribution area of marsh wetlands in China [41]. The dominant native wetland plant generally includes Astragalus, Artemisia, Carex, Phragmites, Potamogeton, Polygonum, Salix, Adenophora, Allium, Chenopodium, Vicia, Corispermum, and Ranunculus [29].

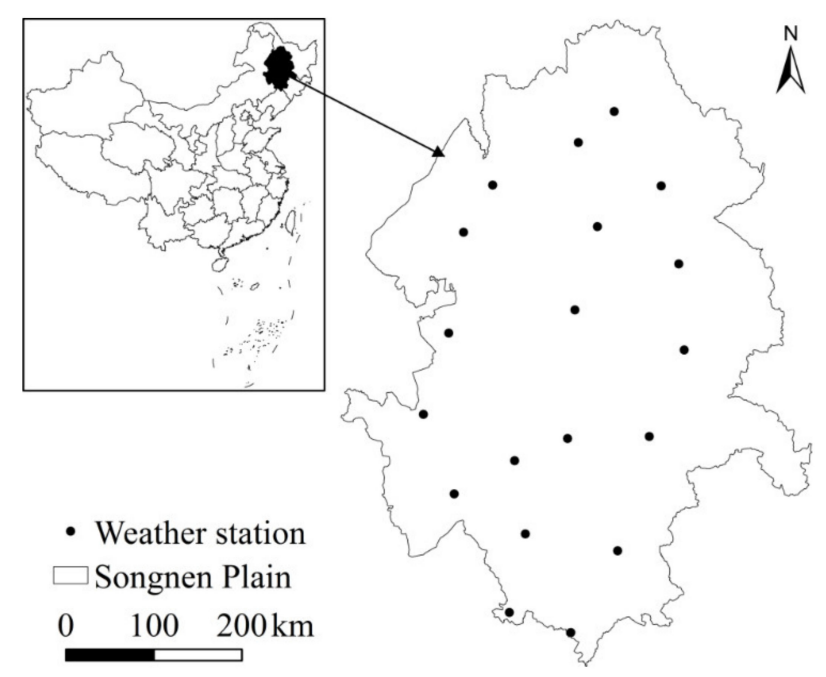

Figure 1. Location of the Songnen Plain in China and distribution of 19 weather stations used in this study. 


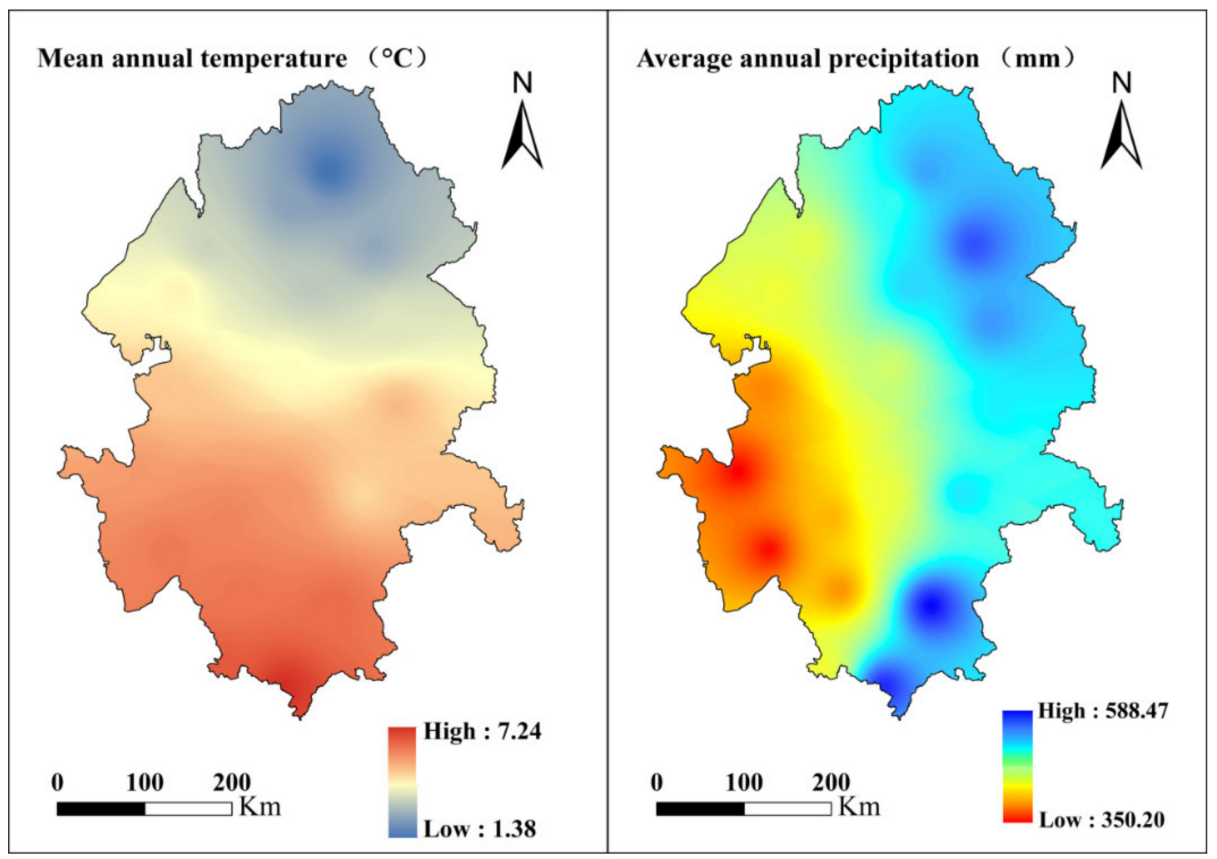

Figure 2. Spatial patterns of the mean annual temperature $\left({ }^{\circ} \mathrm{C}\right)$ and average annual precipitation $(\mathrm{mm})$ in the Songnen Plain marshes averaged from 2000 to 2016.

\subsection{Data}

In this study, we used monthly average surface air temperature $\left(T_{\operatorname{mean}}, \mathrm{T}_{\max }\right.$, and $\left.\mathrm{T}_{\min }\right)$ and precipitation data during 2000-2016 from 19 weather stations distributed in the Songnen plain. These data were provided by the National Meteorological Information Center of China and were processed from daily temperature and precipitation dataset. The data quality of these data was guaranteed with a vigorous data assurance policy [38,42]. Normalized Difference Vegetation Index (NDVI) is defined as the difference between the red and near-infrared (NIR) reflectance divided by their sum $[43,44]$. As a good indicator of vegetation growth, NDVI correlates very well with vegetation coverage and primary productivity [45]. Amongst remotely sensed data from satellites, NDVI has been widely used to investigate the relationship between climate variation and vegetation growth because of its good quality [46-48]. To analyze vegetation change and its response to climate change, this study collected the Moderate Resolution Imaging Spectrometer (MODIS) NDVI data from 2000 to 2016, with a temporal resolution of 16 days and $250 \times 250 \mathrm{~m}$ spatial resolution. Based on pixel reliability parameters, the initial quality control of these MODIS NDVI datasets was made to minimize their errors and biases [49]. In addition, two raster maps of marshes distribution were used in this study. These two maps of marsh distribution were provided by the Chinese Academy of Sciences, the accuracy of which was evaluated based on field survey [45]. By comparing these two periods of marsh distribution data in the Songnen Plain, we found that the loss in the area of marshes was $2300 \mathrm{~km}^{2}$, and the numbers of marsh patches increased by 45 during 2000-2016. The results are generally consistent with previous studies [10,50]. In order to reduce the possible impacts of land use change (e.g., marshes loss) on our results, this study only chose and analyzed the unchanged marshes in the Songnen Plain during the study period. However, it should also be acknowledged that it may not completely exclude the possible effects of wetland degradation and human activities, such as grazing, on our results, although we focused on the unchanged marshes.

\subsection{Methods}

According to previous studies, the growing season is defined as the period from May to September in the Songnen Plain [51]. Considering that the growth of vegetation mainly concentrates in the 
growing season $[52,53]$, this study only investigates the spatiotemporal changes of the NDVI and climate factors during the growing season of 2000-2016. To further reduce the effects of atmosphere and clouds, solar angle on NDVI data, the Maximum Value Compositing (MVC) method was used to reconstruct the original NDVI data into the monthly NDVI data set [54,55]. According to the MVC method, the equation to calculate NDVI can be described as:

$$
\mathrm{MNDVI}_{j}=\operatorname{Max}\left(N D V I_{1}, N D V I_{2}\right)
$$

where $M N D V I_{j}$ means the largest NDVI value for month $j, j$ was the number of the study period (May to September), $N D V I_{1}$ and $N D V I_{2}$ mean NDVI value for the first and second half of $a$ month, respectively.

We used simple linear regression to calculate the trends of the NDVI and climate factors in this study [56]. The trend of NDVI at each pixel is described as follows:

$$
\text { Slope }=\frac{n * \sum_{i=1}^{n} i * N D V I_{i}-\left(\sum_{i=1}^{n} i\right)\left(\sum_{i=1}^{n} N D V I_{i}\right)}{n * \sum_{i=1}^{n} i^{2}-\left(\sum_{i=1}^{n} i\right)^{2}}
$$

where Slope was the trend of NDVI, $n$ was the number of studied years (in this study, $n=17$ years), $i$ was the ordinal number of the year, and $N D V I_{i}$ means the NDVI value for year $i$.

To investigate the possible effects of climate change on the NDVI, correlation coefficients between monthly NDVI and temperature ( $T_{\operatorname{mean}}, \mathrm{T}_{\max }$, and $\left.\mathrm{T}_{\min }\right)$, total precipitation was calculated according to the following formula:

$$
R_{x y}=\frac{\sum_{i=1}^{n}\left(x_{i}-\bar{x}\right)\left(y_{i}-\bar{y}\right)}{\sqrt{\sum_{i=1}^{n}\left(x_{i}-\bar{x}\right)^{2}} \sqrt{\sum_{i=1}^{n}\left(y_{i}-\bar{y}\right)^{2}}}
$$

where $R_{x}$ and $R_{y}$ are the correlation coefficients between variable $x$ and $y, x_{i}$ is the NDVI for year $i$, and $y_{i}$ is the temperature $\left(\mathrm{T}_{\operatorname{mean}}, \mathrm{T}_{\max }\right.$, and $\mathrm{T}_{\min }$ ) or total precipitation for year $i, \bar{x}$ and $\bar{y}$ are the averaged NDVI and temperature $\left(\mathrm{T}_{\operatorname{mean}}, \mathrm{T}_{\max }\right.$, and $\left.\mathrm{T}_{\min }\right)$ or total precipitation for all years. In this study, the average values of NDVI, precipitation, and temperature for marshes were obtained from the averages of all grid cells belonging to the marshes [28,34].

Considering the possible interactions between different climatic factors, partial least-squares (PLS) regression analysis [57] was also used to further test the impacts of precipitation and temperature on NDVI. A model coefficient (MC) and a Variable-Importance-in-the-Projection (VIP) value were calculated for each independent variable [45,57]. In PLS regression, we set the monthly average temperature and precipitation as the independent and monthly NDVI as the dependent variable for each pixel. According to previous studies, variables with VIP equal or greater than 0.8 are considered important for the model $[45,57]$. Compared with conventional regression approaches, PLS regression avoids the problem of autocorrelation between independent factors, such as the climatic factors of the individual months [45]. Due to its good performance, PLS regression has been widely used in analyzing the relationships between the dependent and independent variables [57].

\section{Results}

\subsection{Spatiotemporal Change of NDVI in the Songnen Plain Marshes}

From 2000 to 2016, the growing season mean NDVI (referred to as the growing season NDVI hereafter) of marshes significantly increased by $0.06 /$ decade over the Songnen Plain $(p<0.01)$. In different months of the growing season, monthly NDVI of marshes similarly increased significantly during the study period (Figure 3), with the largest increasing trends in May, June, and July (0.06/decade, 0.10/decade, $0.07 /$ decade, respectively). 

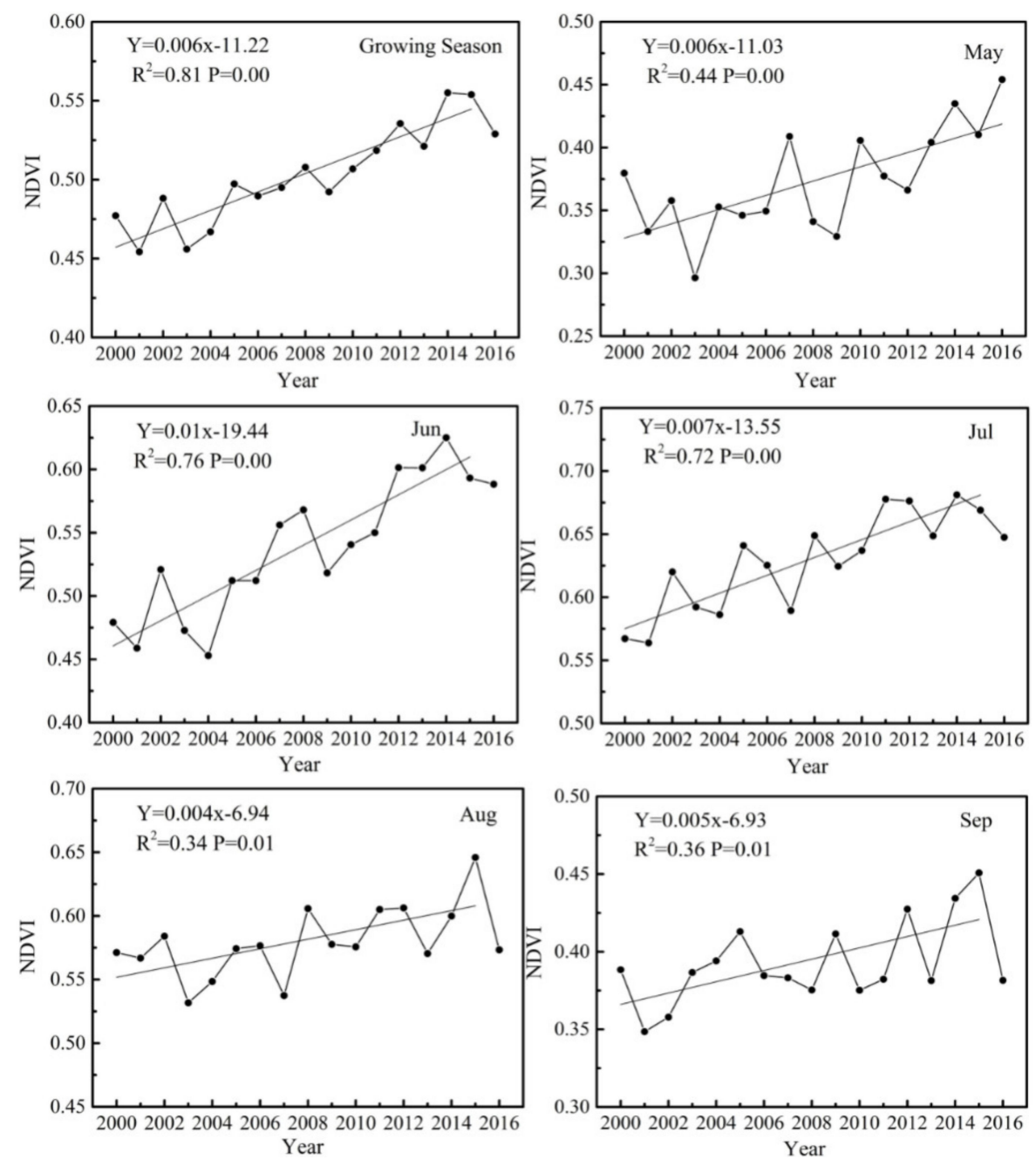

Figure 3. Temporal changes of NDVI in the Songnen Plain marshes during 2000-2016. $p<0.05$ and $p<0.01$ indicate significance at the $95 \%$ and $90 \%$ level.

Spatially, the changes of NDVI had apparent spatial heterogeneities in the Songnen Plain marshes from 2000 to 2016 (Figure 4). The growing season NDVI increased in 84\% of the marshes in the study area, with the most obvious increase of NDVI in the central and south of Songnen Plain. By contrast, the reduced growing season NDVI accounted for only $13 \%$ of the marshes in the study area, which was mainly concentrated in the northeast of Songnen Plain (Figure 4). During the growing season, the spatial patterns of the monthly NDVI trend were generally similar to that of the growing season NDVI trend. However, the monthly average NDVI in August showed an obvious decreasing trend in the marshes of the central and south of Songnen Plain (Figure 4).

\subsection{The Effects of Recent Climate Change on NDVI of Marshes}

Table 1 shows the correlations between the NDVI and temperature and precipitation for the whole marshes of the Songnen Plain. We found a significant positive relationship between the growing season precipitation with the growing season NDVI of the whole marshes in the Songnen Plain $(p<0.05)$. There was a moderately negative relationship between the growing season temperature and NDVI of the whole marshes in the Songnen Plain $(p>0.05)$. In addition, our results showed opposite effects of the growing season $\mathrm{T}_{\max }$ and $\mathrm{T}_{\min }$ on the growing season NDVI of the Songnen Plain marshes: The growing season NDVI had a negative correlation with $\mathrm{T}_{\max }$, but had a positive correlation with $\mathrm{T}_{\min }$ (Table 1). 


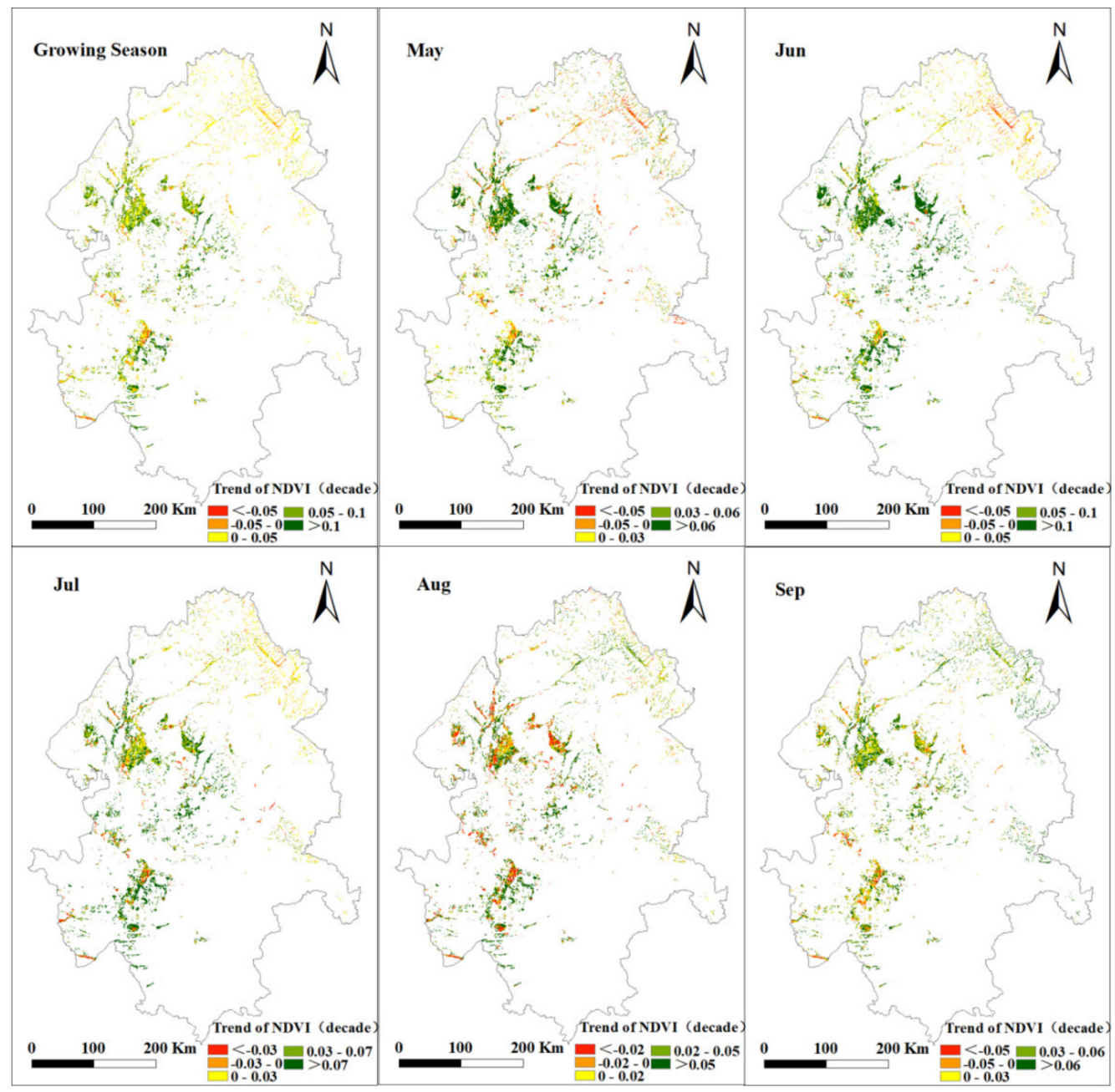

Figure 4. Spatial patterns of the growing season and monthly NDVI trends in the marshes of the Songnen Plain from 2000 to 2016.

Table 1. Correlations between climate variables (precipitation, $T_{\operatorname{mean}}, T_{\max }$, and $T_{\min }$ ) and NDVI of the Songnen Plain marshes, based on Pearson correlation analysis.

\begin{tabular}{ccccc}
\hline & $\mathrm{T}_{\text {mean }}$ & $\mathrm{T}_{\max }$ & $\mathrm{T}_{\min }$ & Precipitation \\
\hline Growing Season & -0.266 & -0.409 & 0.260 & $0.559^{*}$ \\
May & -0.234 & -0.332 & 0.239 & $0.735^{* *}$ \\
June & -0.123 & -0.228 & 0.180 & 0.339 \\
July & -0.165 & -0.312 & 0.217 & 0.252 \\
August & 0.211 & 0.165 & 0.339 & -0.171 \\
September & -0.174 & -0.351 & 0.148 & 0.417 \\
\hline
\end{tabular}

Significant at ${ }^{*} p<0.05$ and ${ }^{* *} p<0.01$ levels.

To further investigate the impacts of climate change on NDVI of the Songnen Plain marshes, we calculated the correlation between monthly NDVI and precipitation and temperature (Table 1). The results showed that precipitation had a positive relationship with NDVI of marshes in all the months of the growing season, with the exception in August. Moreover, the positive correlation between precipitation and NDVI reached a significant level in May $(p<0.01)$. In August, however, we found a negative relationship of precipitation with NDVI of the Songnen Plain marshes. In terms of temperature impacts, we found that the monthly $\mathrm{T}_{\text {mean }}$ had a positive correlation with NDVI in August, but had a negative correlation with NDVI in other months (Table 1). For the effects of daytime 
and night-time temperatures, we found asymmetric effects of $T_{\max }$ and $T_{\min }$ on NDVI of the Songnen Plain marshes. Similar to the growing season results, there were opposite effects of daytime $T_{\max }$ and nighttime $T_{\min }$ on NDVI of marshes for all the months of the growing seasons except August. By contrast, both $\mathrm{T}_{\max }$ and $\mathrm{T}_{\min }$ had a positive relationship with NDVI in August (Table 1).

Based on the PLS regression, we also found that the NDVI was strong positively correlated with precipitation in the growing season (Figure 5). By contrast, the mean temperature had a weak negative relationship with the growing season NDVI. Consistent with correlation analysis results, the PLS regression also showed asymmetric effects of the growing season $\mathrm{T}_{\max }$ and $\mathrm{T}_{\min }$ on the growing season NDVI of marshes: The growing season NDVI was strong negatively associated with $\mathrm{T}_{\max }$, but was strong positively associated with $\mathrm{T}_{\min }$ in the Songnen Plain marshes. For different months, all the PLS regression results also confirmed our findings about the effects of monthly temperature (including $\mathrm{T}_{\text {mean }}, \mathrm{T}_{\max }$, and $\mathrm{T}_{\min }$ ) and precipitation on NDVI based on the correlation analysis results. The only slight difference between the results from PLS regression and correlation analysis was the different significance level for the effect of the climatic variable on NDVI, which is actually reasonable due to different statistical methods.
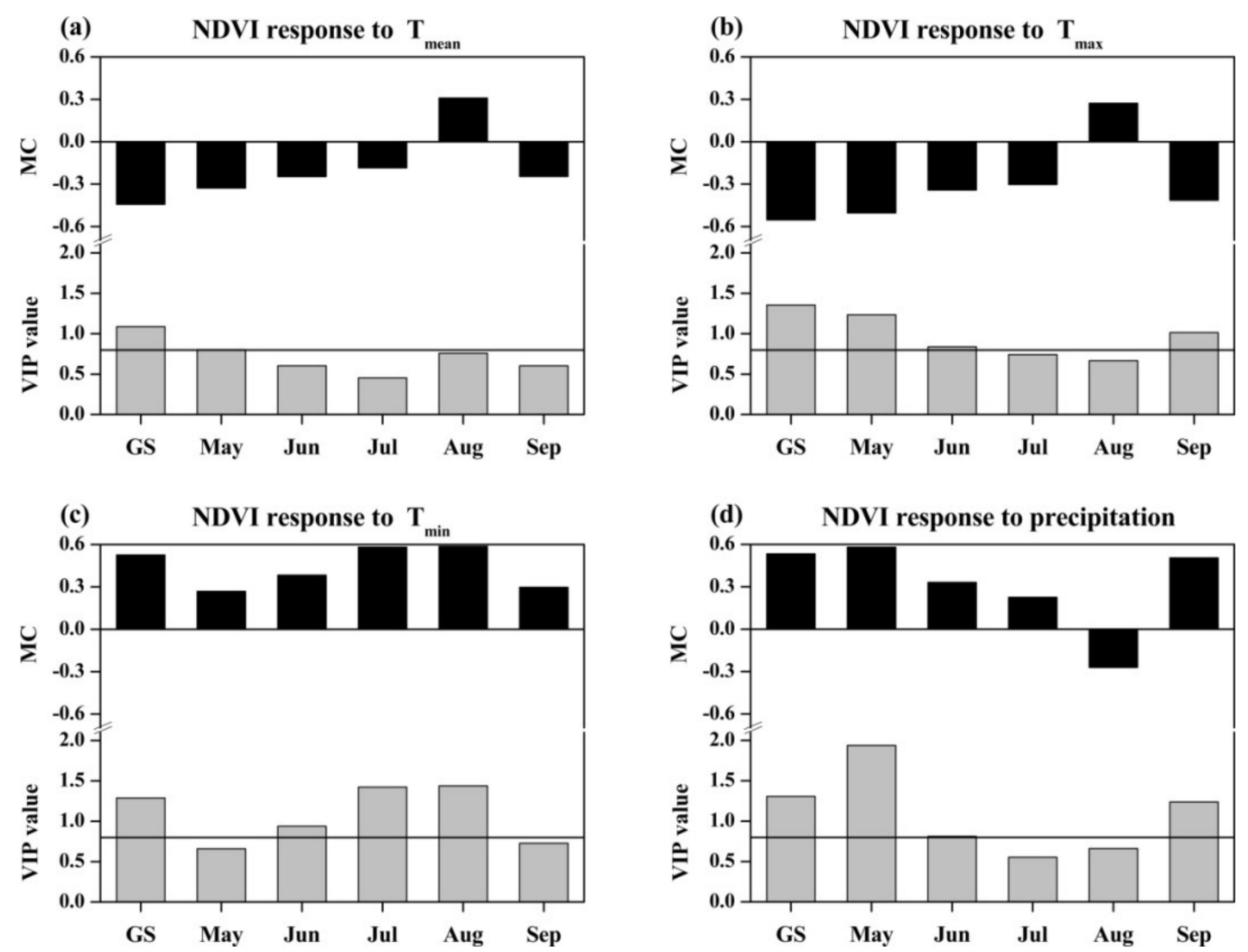

Figure 5. Response of NDVI of the Songnen Plain marsh to temperature (including $T_{\text {mean }}, T_{\max }$, and $\mathrm{T}_{\min }$ ) and precipitation change based on partial least-squares (PLS) regression. Model coefficients (MC) and the variable importance plots (VIP) values reflect the degree and the significance of the impact of climatic factors on the NDVI, respectively. GS refers to the whole growing season (May to September). We set the NDVI as the dependent variable and precipitation, $T_{\text {mean }}, T_{\max }$ and $T_{\min }$ as the independent variables.

Spatially, the negative correlation between the growing season NDVI and precipitation was only concentrated in the north of Songnen Plain. The positive correlations between NDVI and temperature were also concentrated in the north of Songnen Plain. These opposite effects of $T_{\max }$ and $T_{\min }$ were more obvious in the central and north of the study area (Figure 6). Similar to the growing season results, the spatial correlations between monthly NDVI and precipitation, $\mathrm{T}_{\text {mean }}, \mathrm{T}_{\max }$, and $\mathrm{T}_{\min }$ have apparent 
spatial heterogeneities in the Songnen Plain marshes (Figure 7). With the exception of August, these were obviously asymmetric effects of $\mathrm{T}_{\max }$ and $\mathrm{T}_{\min }$ on NDVI in the central and north of the study area, which was consistent with the growing season results. In August, however, there are positive effects of both $\mathrm{T}_{\max }$ and $\mathrm{T}_{\min }$ on NDVI in most parts of the study area. Different from the results of the growing season and other months, precipitation in August had a significantly negative relationship with NDVI of marshes in the north of Songnen Plain.

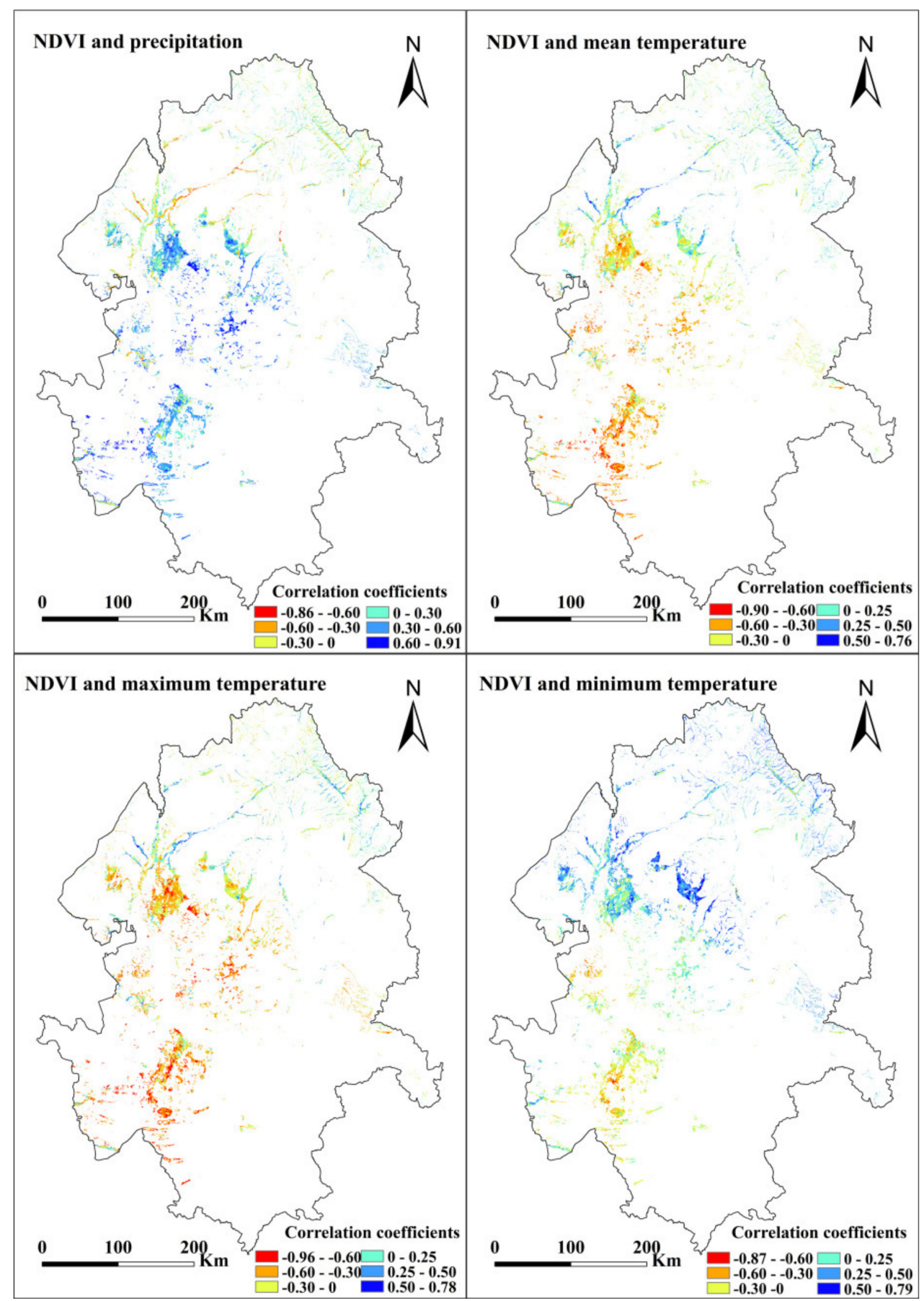

Figure 6. Spatial distributions of correlation coefficients between the growing season NDVI and the growing season precipitation, $\mathrm{T}_{\operatorname{mean}}, \mathrm{T}_{\max }$ and $\mathrm{T}_{\min }$ in the Songnen Plain marshes. 


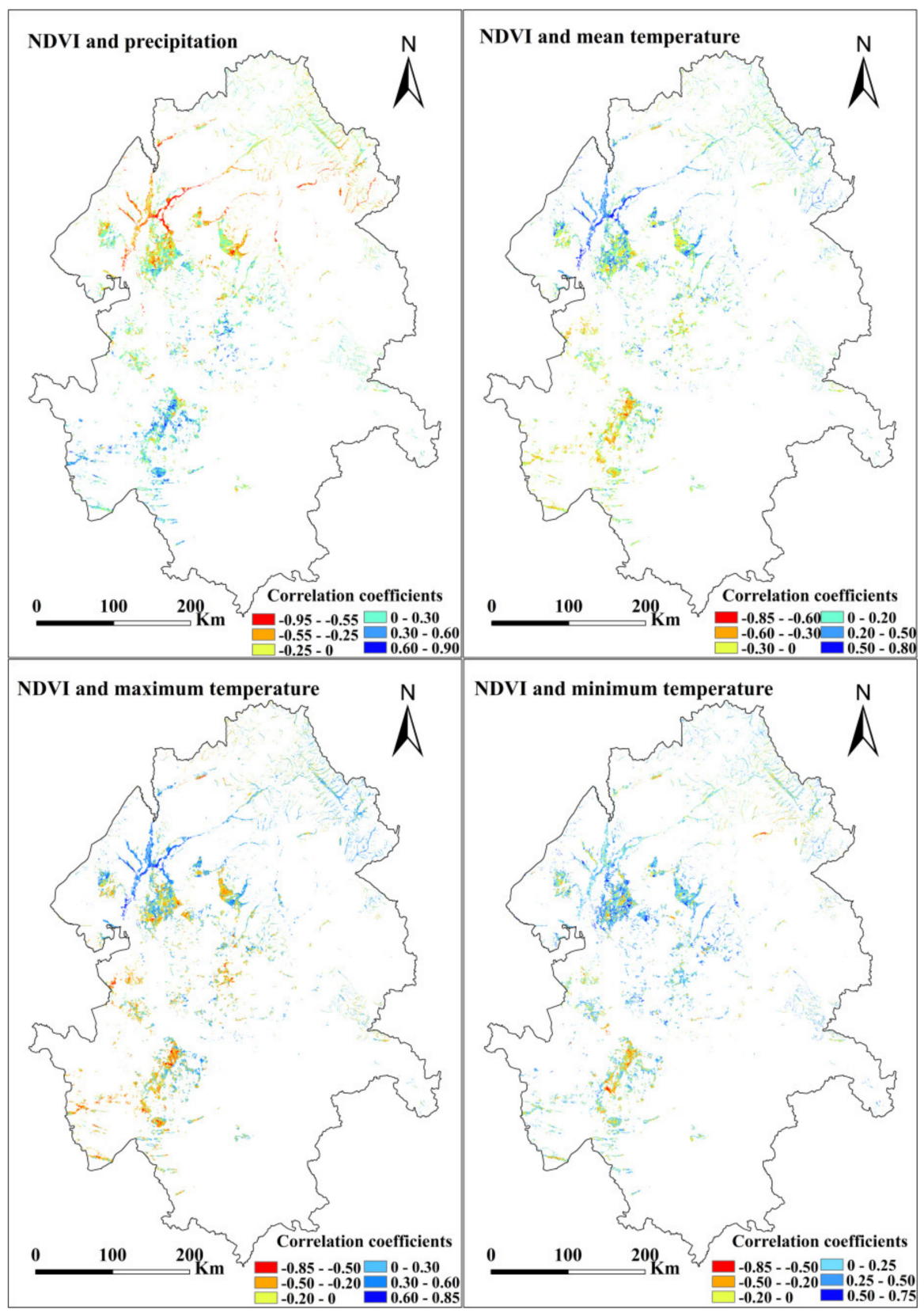

Figure 7. Spatial distributions of correlation coefficients between the NDVI and precipitation, $\mathrm{T}_{\text {mean, }}$ $\mathrm{T}_{\max }$ and $\mathrm{T}_{\min }$ in August on the Songnen Plain marshes.

\section{Discussion}

\subsection{The Correlations between Climate Variables and NDVI of the Songnen Plain Marshes}

Over the whole marshes of the Songnen Plain, the growing season NDVI had a significant positive relationship with the growing season precipitation but had a weak negative correlation with temperature. These results suggest that, in recent years, the growing season NDVI has been mainly affected by precipitation and increasing precipitation could promote the growth of vegetation in the growing season. This finding was consistent with Shen et al. (2019), who found that the vegetation of marshes is mainly affected by precipitation in arid and semi-arid regions of northeast China.

By further analyzing the relationships of NDVI with daytime and nighttime temperature, we first found asymmetric effects of $T_{\max }$ and $T_{\min }$ on NDVI of the Songnen Plain marshes. The growing 
season NDVI was negatively correlated with $\mathrm{T}_{\max }$, but positively correlated with $\mathrm{T}_{\min }$ in the Songnen Plain marshes. This result indicates that daytime and night-time warming could prohibit and promote marsh vegetation growth in the Songnen Plain, respectively. In arid and semi-arid Songnen Plain, it is reported that warm daytime temperature could limit the growth of vegetation by enhancing evaporation and reducing soil water content [58]. By contrast, night-time warming may promote the growth of vegetation due to a rebound effect of compensatory stimulated photosynthesis in the next day $[37,59]$. These explanations may account for the asymmetric effects of daytime and night-time warming on NDVI of the Songnen Plain marshes.

In different months, we found that the precipitation had a negative relationship with NDVI in August, but had a positive correlation with NDVI in the other months. By contrast, the temperature had a positive relationship with NDVI of marshes in August but had a negative correlation with NDVI in the other months. The results of correlation analysis indicate that the NDVI was determined by precipitation and increasing precipitation could promote the growth of vegetation in most months of the growing season. In August, however, warm temperature could promote the growth of vegetation, and increasing precipitation had adverse impacts on vegetation growth. This may be because the precipitation in the Songnen Plain is the largest in August when the temperature becomes a limit factor affecting vegetation growth [16], and thus warm temperature is beneficial to the vegetation growth by enhancing photosynthesis [60]. In different months, we also found asymmetric effects of $T_{\max }$ and $\mathrm{T}_{\min }$ on NDVI of marshes in May, June, July, and September. It indicates that warming daytime $\mathrm{T}_{\max }$ and nighttime $\mathrm{T}_{\min }$ will limit and promote the growth of vegetation in these months, respectively.

For the spatial correlations, the growing season precipitation generally had a positive relationship with the growing season NDVI, with the negative correlation only scattered in the north of Songnen Plain $(p<0.01)$. By contrast, there was a generally negative correlation between the growing season temperature and NDVI, with a positive correlation in the north of Songnen plain. The reason for this phenomenon may be because the temperature becomes a limit factor for vegetation growth in the north of Songnen Plain, where the temperature is relatively low due to high latitude. As a result, warm temperature promotes vegetation growth, but increasing precipitation is harmful to the growth of vegetation because of the low temperature caused by precipitation [34,40]. According to previous studies, the main vegetation types of marshes include Phragmites australis and Carex, which are mainly distributed in the north and south of Songnen Plain, respectively [61-63]. In the north of Songnen Plain, the water content is relatively abundant and temperature becomes the limit factor affecting the growth of Phragmites australis. It is reported that low temperatures caused by precipitation can limit the absorption of nutrition by plant roots and thus prohibits Phragmites australis growth of marshes [64]. In the south of Songnen Plain, the growth of Carex was mainly affected by the precipitation due to limited water content in the seasonal marsh regions. The different growth strategies of these two vegetation types [65] may partly explain the opposite effects of precipitation on NDVI in the north and south of marshes in the Songnen Plain.

\subsection{Vegetation Change in the Songnen Plain Marshes}

To further explain the temporal changes of NDVI in the Songnen Plain marshes, we analyzed the changes in temperature and precipitation during the study period. The results show that the growing season total precipitation significantly increased by $18.5 \mathrm{~mm} /$ decade $(p<0.05)$, but the growing season mean temperature showed a weak declining trend $\left(-0.3^{\circ} \mathrm{C} /\right.$ decade) (Figure 8$)$. In addition, there were opposite changes of the growing season $\mathrm{T}_{\max }$ and $\mathrm{T}_{\min }$ : The growing season $\mathrm{T}_{\max }$ showed a weak declining trend $\left(-0.07^{\circ} \mathrm{C} /\right.$ decade), but the growing season $\mathrm{T}_{\min }$ showed a weak increasing trend $\left(0.02{ }^{\circ} \mathrm{C} /\right.$ decade) during 2000 to 2016 (Figure 8). For different months, we found significant increasing precipitation in May, June, and September $(3.77 \mathrm{~mm} /$ decade, $2.96 \mathrm{~mm} /$ decade and $3.25 \mathrm{~mm} / \mathrm{decade}$, respectively) and a significant decreasing trend of $\mathrm{T}_{\min }$ in May, June, and September $\left(-0.10^{\circ} \mathrm{C} /\right.$ decade, $-0.10^{\circ} \mathrm{C} /$ decade and $-0.09^{\circ} \mathrm{C} /$ decade, respectively) from 2000 to 2016 (Table 2). 

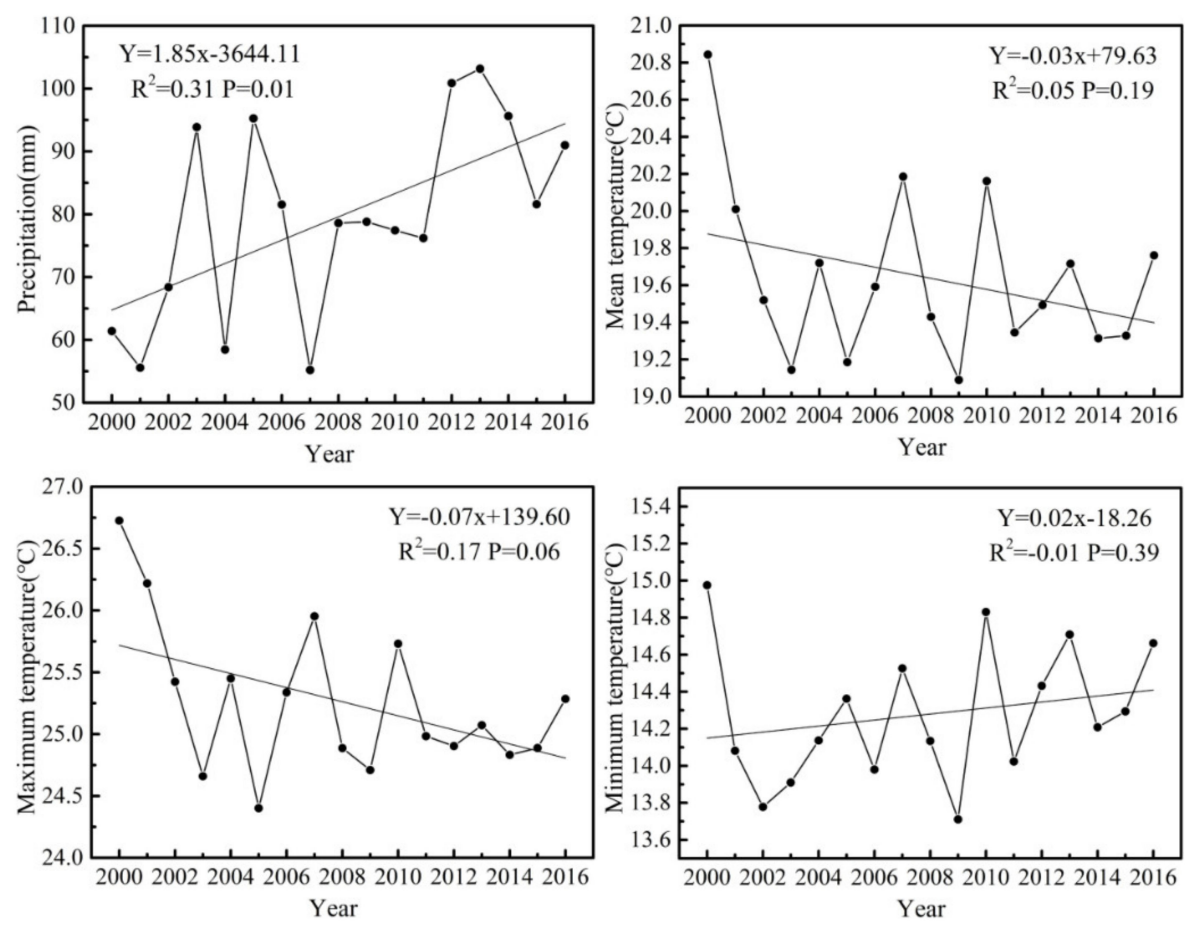

Figure 8. Temporal changes of the growing season precipitation and temperatures $\left(\mathrm{T}_{\text {mean }}, \mathrm{T}_{\max }\right.$, and $\mathrm{T}_{\min }$ ) in the Songnen Plain during 2000-2016. $p<0.05$ and $p<0.01$ indicate significance at the $95 \%$ and $90 \%$ levels, respectively.

Table 2. The variation trends of monthly temperatures $\left({ }^{\circ} \mathrm{C} /\right.$ decade $)$ and precipitation $(\mathrm{mm} /$ decade $)$ in marshes of the Songnen Plain during 2000-2016.

\begin{tabular}{ccccc}
\hline & $\mathrm{T}_{\text {mean }}$ & $\mathrm{T}_{\max }$ & $\mathrm{T}_{\text {min }}$ & Precipitation \\
\hline May & -0.05 & $-0.10^{*}$ & 0.02 & $3.77^{* *}$ \\
June & -0.05 & $-0.10^{*}$ & 0.03 & $2.96^{*}$ \\
July & -0.01 & -0.03 & 0.003 & 0.81 \\
August & 0.01 & 0.03 & 0.04 & 0.83 \\
September & -0.61 & $-0.09 *$ & -0.01 & $3.25^{*}$ \\
\hline
\end{tabular}

Significant at ${ }^{*} p<0.05$ and ${ }^{* *} p<0.01$ levels.

Based on the results of correlations between climate variables (precipitation, $\mathrm{T}_{\text {mean }}, \mathrm{T}_{\max }$, and $\mathrm{T}_{\min }$ ) and NDVI (Table 2, Figure 3), we concluded that the increasing growing season precipitation accounts for the increasing growing season NDVI of the Songnen Plain marshes. For different months, the significantly increasing precipitation and decreasing $\mathrm{T}_{\min }$ may partly explain the NDVI increase in May, June, and September. In August, although the increasing temperature was likely to promote the growth of vegetation, the increasing precipitation could have exerted negative effects on the vegetation growth, which partly explains the weak increasing NDVI in August.

Spatially, the growing season NDVI of marshes in the Songnen Plain significantly increased during 2000-2016, with the largest increase of NDVI in the central and south of Songnen Plain $(p<0.01)$ (Figure 4). Interestingly, we found the growing season precipitation showed the largest increase in the central and south of Songnen Plain (Figure 9). Therefore, the most obvious increase in the growing season precipitation in the central and south of Songnen Plain seems to explain the largest increase of NDVI of marshes in these regions. In August, the monthly precipitation of marshes showed an obvious decreasing trend in the central and south of Songnen Plain (Figure 10), which may partly account for the moderate decrease of NDVI in the marshes of these regions. 


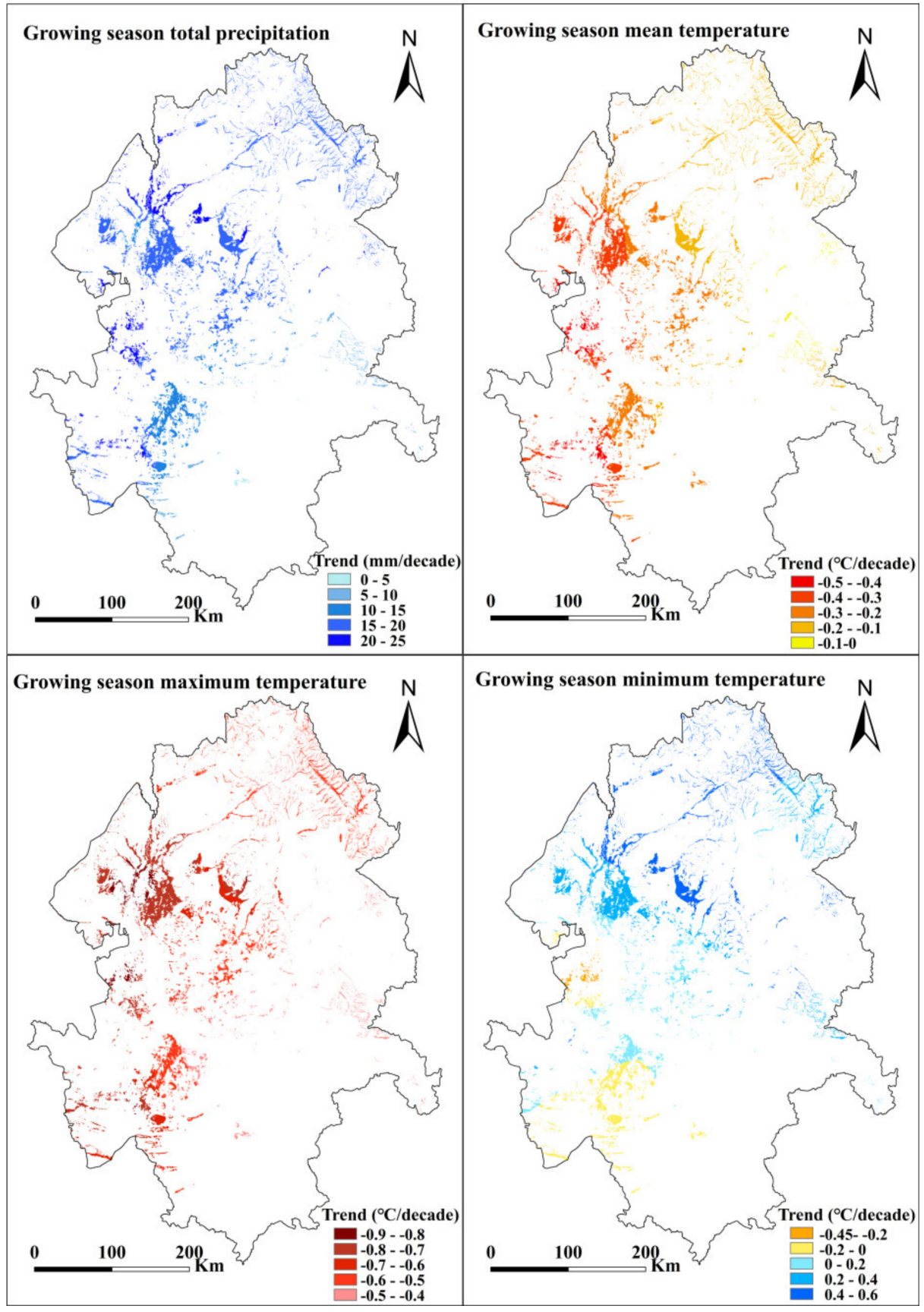

Figure 9. Spatial variation trends of the growing season climate variables (precipitation, $\mathrm{T}_{\operatorname{mean}}, \mathrm{T}_{\max }$, and $\mathrm{T}_{\min }$ ) in marshes of the Songnen Plain from 2000 to 2016.

Previous studies found that the marshes in the north of Songnen Plain have undergone obvious loss and degradation due to human activities [63]. In this study, we found that the reduced growing season NDVI was mainly concentrated in the northeast of Songnen Plain. Considering that the marsh loss and degradation can have obvious adverse effects on marsh vegetation [10], the marsh loss and degradation in the northeast of Songnen Plain may partly account for the decrease of NDVI in marshes of these regions. In order to restore the degraded marshes, some marsh restoration projects have been implemented by local governments in the central of Songnen Plain during recent years [10]. For example, a project of "diverting the Nenjiang River to the Momoge" was implemented in the Momoge region since 2002 to restore the degraded wetlands [66]. Through the implementation of a series of marshes restoration projects, the ecological environment and the vegetation coverage 
conditions have been greatly improved [67]. In this study, it is interesting to note that the largest increase of the growing season NDVI was concentrated in the central of Songnen Plain during 2000-2016. Therefore, it is likely that the ecological restoration project in the central of Songnen Plain may also partly explain the obvious increase of NDVI in this region [68].

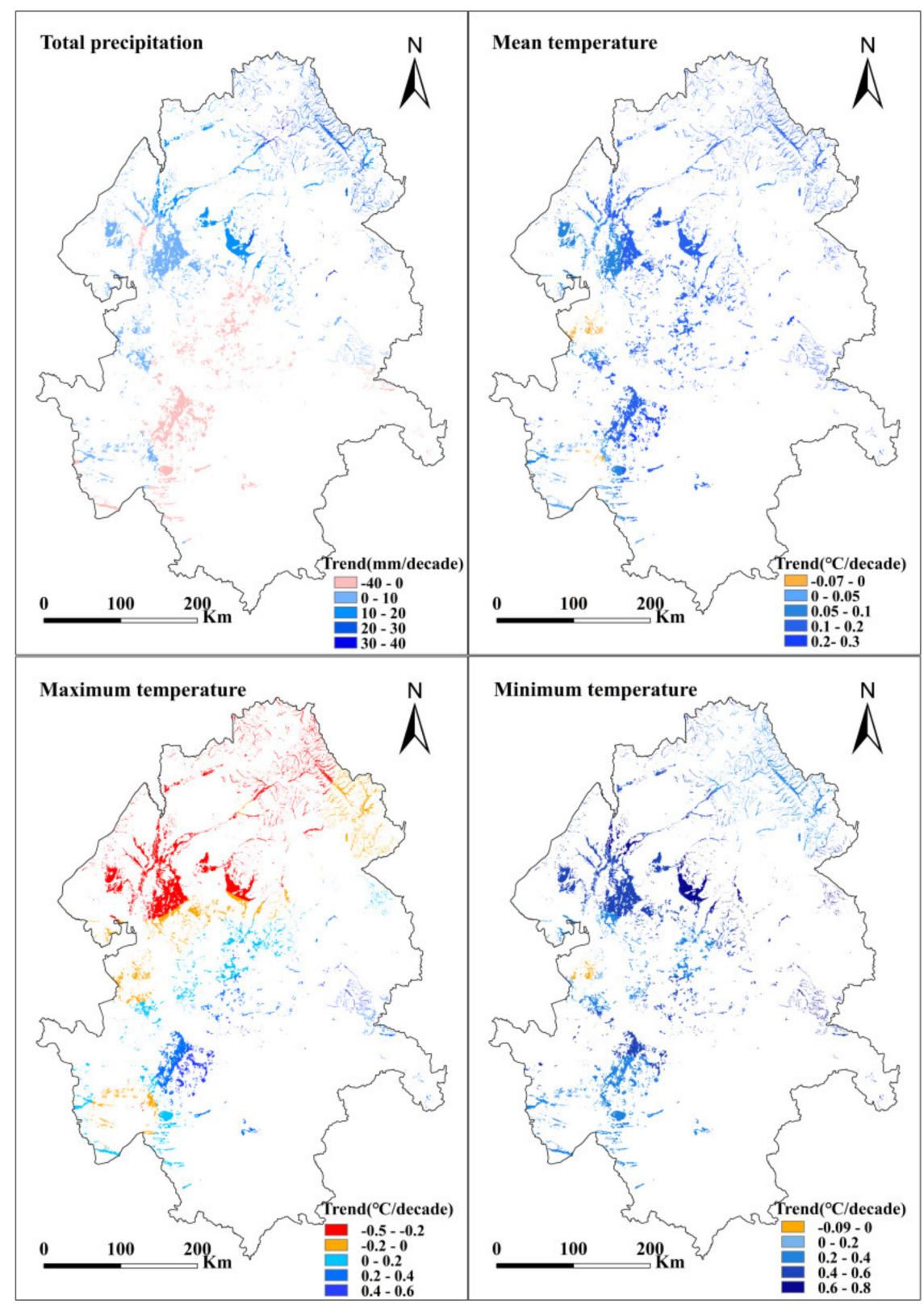

Figure 10. Spatial variation trends of precipitation and temperatures in August on marshes of the Songnen Plain from 2000 to 2016.

\section{Conclusions}

Based on NDVI and climate data from 2000 to 2016, this study analyzed the spatiotemporal change in NDVI and the possible impact of precipitation and temperature (including $T_{\text {mean }}, T_{\max }$, and $\mathrm{T}_{\min }$ ) on growth vegetation during the growing seasons. During 2000-2016, the growing season NDVI of marshes significantly increased at a rate of 0.06/decade over the whole Songnen Plain. Spatially, the changes of NDVI had apparent spatial heterogeneities in marshes, and the most obvious increase of vegetation was concentrated in the central and south of Songnen Plain. The results of correlation 
analysis indicated that the vegetation growth was determined by precipitation and the increased growing season precipitation could promote the growth of marsh vegetation in the Songnen Plain. By contrast, warmer growing season temperatures could inhibit vegetation growth, possibly due to warming-induced water deficiency. In August, however, we found that temperatures had a positive effect, but precipitation had a negative effect on the growth of marsh vegetation in the Songnen Plain. This phenomenon may be related to the fact that the amount of precipitation in the study area is the largest in August, when the precipitation is abundant for the vegetation growth, and warming temperatures are beneficial to vegetation growth by enhancing photosynthesis. In addition, this study first found asymmetric effects of daytime $T_{\max }$ and nighttime $T_{\min }$ on NDVI of the Songnen Plain marshes: The NDVI correlated negatively with $\mathrm{T}_{\max }$ but positively with $\mathrm{T}_{\min }$ in May, June, July, and September. It indicates that warming daytime and nighttime temperatures could have negative and positive effects on vegetation growth in the Songnen Plain marshes, respectively. Under the background of global asymmetric warming, we should pay more attention to these asymmetric effects of $\mathrm{T}_{\max }$ and $\mathrm{T}_{\min }$ on marsh vegetation, especially when it comes to modeling the changes in wetland vegetation caused by climate change in the Songnen Plain of Northeast China.

It should be noted that there may exist some limitations in the current study. First, the NDVI data with a resolution of 15 days could contain some uncertainties due to the effects of clouds, atmosphere, and solar angle. In addition, each NDVI pixel could only roughly reflect the conditions of vegetation within $250 \times 250 \mathrm{~m}$ area. Second, the Maximum Value Compositing (MVC) and the interpolation method may contain some uncertainties. These uncertainties could have some effects on the results of vegetation change and its relationship with climate change in this study. Third, the correlations between NDVI and climate variables are actually more complicated because many other climatic and environmental factors may also have significant effects on NDVI. Further studies are still needed to investigate the possible impacts of other climatic and environmental factors as well as human activities on marsh vegetation in the Songnen Plain.

Author Contributions: Conceptualization, methodology, formal analysis, Y.W., X.S., M.J. and X.L.; writing—original draft preparation, Y.W.; writing - review and editing, X.S. All authors have read and agreed to the published version of the manuscript.

Funding: This work was supported by the National Natural Science Foundation of China (No.41971065), National Key Research and Development Program of China (2019YFC0409100), Youth Innovation Promotion Association, Chinese Academy of Sciences (No.2019235), Outstanding Young Talent Fund Project of Jilin Province (No.20190103013JH), and Key Research Program of Frontier Sciences, Chinese Academy of Sciences (No. ZDBS-LY-7019).

Acknowledgments: The data presented in this paper are publicly available and can be downloaded from http://www.resdc.cn; http://wetland.igadc.cn.

Conflicts of Interest: The authors declare no conflict of interest. The funders had no role in the design of the study; in the collection, analyses, or interpretation of data; in the writing of the manuscript, or in the decision to publish the results.

\section{References}

1. Wei, X.; Wang, S.; Wang, Y. Spatial and temporal change of fractional vegetation cover in North-western China from 2000 to 2010. Geol. J. 2018, 53, 427-434. [CrossRef]

2. Shen, X.J.; Liu, B.H.; Jiang, M.; Lu, X.G. Marshland loss warms local land surface temperature in China. Geophys. Res. Lett. 2020, 47, e2020GL087648. [CrossRef]

3. Brown, J.F.; Howard, D.; Wylie, B.; Frieze, A.; Ji, L.; Gacke, C. Application-Ready Expedited MODIS Data for Operational Land Surface Monitoring of Vegetation Condition. Remote Sens. 2015, 7, 16226-16240. [CrossRef]

4. Kim, D.; Cairns, D.M.; Bartholdy, J. Environmental controls on multiscale spatial patterns of salt marsh vegetation. Phys. Geogr. 2010, 31, 58-78. [CrossRef]

5. Moffett, K.B.; Robinson, D.A.; Gorelick, S.M. Relationship of Salt Marsh Vegetation Zonation to Spatial Patterns in Soil Moisture, Salinity, and Topography. Ecosystems. 2010, 13, 1287-1302. [CrossRef] 
6. Li, X.; Ren, L.; Liu, Y.; Craft, C.; Mander, U.; Yang, S. The impact of the change in vegetation structure on the ecological functions of salt marshes: The example of the Yangtze estuary. Reg. Environ Chang. 2014, 14, 623-632. [CrossRef]

7. Sang, H.; Zhang, J.; Lin, H.; Zhai, L. Multi-Polarization ASAR Backscattering from Herbaceous Wetlands in Poyang Lake Region, China. Remote Sens. 2014, 6, 4621-4646. [CrossRef]

8. Whitehouse, H.E.; Bayley, S.E. Vegetation patterns and biodiversity of peatland plant communities surrounding mid-boreal wetland ponds in Alberta, Canada. Can. J. Bot. 2005, 83, 621-637. [CrossRef]

9. Radabaugh, K.R.; Moyer, R.P.; Chappel, A.R.; Powell, C.E.; Bociu, I.; Clark, B.C.; Smoak, J.M. Coastal Blue Carbon Assessment of Mangroves, Salt Marshes, and Salt Barrens in Tampa Bay, Florida, USA. Estuar. Coast. 2018, 41, 1496-1510. [CrossRef]

10. Shen, X.J.; Xue, Z.S.; Jiang, M.; Lu, X.G. Spatiotemporal Change of Vegetation Coverage and its Relationship with Climate Change in Freshwater Marshes of Northeast China. Wetlands 2019, 39, 429-439. [CrossRef]

11. Liu, H.; Zhang, M.; Lin, Z.; Xu, X. Spatial heterogeneity of the relationship between vegetation dynamics and climate change and their driving forces at multiple time scales in Southwest China. Agric. For. Meteorol. 2018, 256, 10-21. [CrossRef]

12. Bachelet, D.; Neilson, R.P.; Lenihan, J.M.; Drapek, R.J. Climate change effects on vegetation distribution and carbon budget in the United States. Ecosystems 2001, 4, 164-185. [CrossRef]

13. Wu, D.H.; Zhao, X.; Liang, S.L.; Zhou, T.; Huang, K.C.; Tang, B.J.; Zhao, W.Q. Time-lag effects of global vegetation responses to climate change. Glob. Chang. Biol. 2015, 21, 3520-3531. [CrossRef]

14. Sykes, M.T.; Prentice, I.C.; Laarif, F. Quantifying the impact of global climate change on potential natural vegetation. Clim. Chang. 1999, 41, 37-52. [CrossRef]

15. Swarth, C.; Delgado, P.; Whigham, D. Vegetation dynamics in a tidal freshwater wetland: A long-term study at differing scales. Estuar. Coast. 2013, 36, 559-574. [CrossRef]

16. Shen, X.J.; Liu, B.H.; Li, G.D.; Yu, P.J.; Zhou, D.W. Impacts of grassland types and vegetation cover changes on surface air temperature in the regions of temperate grassland of China. Theor. Appl. Climatol. 2016, 126, 141-150. [CrossRef]

17. Osland, M.J.; Day, R.H.; Larriviere, J.C.; From, A.S. Aboveground Allometric Models for Freeze-Affected Black Mangroves (Avicennia germinans): Equations for a Climate Sensitive Mangrove-Marsh Ecotone. PLoS ONE 2014, 9, e99604. [CrossRef]

18. Cavanaugh, K.C.; Kellner, J.R.; Forde, A.J.; Gruner, D.S.; Parker, J.D.; Rodriguez, W.; Feller, I.C. Poleward expansion of mangroves is a threshold response to decreased frequency of extreme cold events. Proc. Natl. Acad. Sci. USA 2014, 111, 723-727. [CrossRef]

19. Gabler, C.A.; Osland, M.J.; Grace, J.B.; Stagg, C.L.; Day, R.H.; Hartley, S.B.; Enwright, N.M.; From, A.S.; McCoy, M.L.; McLeod, J.L. Macroclimatic change expected to transform coastal wetland ecosystems this century. Nat. Clim. Chang. 2017, 7, 142-147. [CrossRef]

20. Doughty, C.L.; Langley, J.A.; Walker, W.S.; Feller, I.C.; Schaub, R.; Chapman, S.K. Mangrove Range Expansion Rapidly Increases Coastal Wetland Carbon Storage. Estuar. Coast. 2016, 39, 385-396. [CrossRef]

21. Osland, M.J.; Day, R.H.; Hall, C.T.; Brumfield, M.D.; Dugas, J.L.; Jones, W.R. Mangrove expansion and contraction at a poleward range limit: Climate extremes and land-ocean temperature gradients. Ecology 2017, 98, 125-137. [CrossRef] [PubMed]

22. Osland, M.J.; Day, R.H.; From, A.S.; McCoy, M.L.; McLeod, J.L.; Kelleway, J.J. Life stage influences the resistance and resilience of black mangrove forests to winter climate extremes. Ecosphere 2015, 6, 1-15. [CrossRef]

23. Yando, E.S.; Osland, M.J.; Willis, J.M.; Day, R.H.; Krauss, K.W.; Hester, M.W. Salt marsh-mangrove ecotones: Using structural gradients to investigate the effects of woody plant encroachment on plant-soil interactions and ecosystem carbon pools. J. Ecol. 2016, 104, 1020-1031. [CrossRef]

24. Morrisey, D.J.; Swales, A.; Dittmann, S.; Morrison, M.A.; Lovelock, C.E.; Beard, C.M. Thecology and management of temperate mangroves. In Oceanography and Marine Biology: An Annual Review; Gibson, R.N., Atkinson, R.J.A., Gordon, J.D.M., Eds.; CRC Press: Boca Raton, FL, USA, 2010; Volume 48.

25. Zhang, G.L.; Xu, X.L.; Zhou, C.P.; Zhang, H.B.; Ouyang, H. Responses of grassland vegetation to climatic variations on different temporal scales in HulunBuir Grassland in the past 30 years. J. Geogr. Sci. 2011, 21, 634-650. [CrossRef] 
26. Pang, G.J.; Wang, X.J.; Yang, M.X. Using the NDVI to identify variations in, and responses of, vegetation to climate change on the Tibetan Plateau from 1982 to 2012. Quat. Int. 2017, 444, 87-96. [CrossRef]

27. Fagherazzi, S.; Kirwan, M.L.; Mudd, S.M.; Guntenspergen, G.R.; Temmerman, S.; D'Alpaos, A.; van de Koppel, J.; Rybczyk, J.M.; Reyes, E.; Craft, C.; et al. Numerical models of salt marsh evolution: Ecology, geomorphic, and climatic factors. Rev. Geophys. 2012, 50, Rg1002. [CrossRef]

28. Chen, H.; Zhang, W.C.; Gao, H.R.; Nie, N. Climate Change and Anthropogenic Impacts on Wetland and Agriculture in the Songnen and Sanjiang Plain, Northeast China. Remote Sens. 2018, 10, 356. [CrossRef]

29. Mao, D.H.; Wang, Z.M.; Luo, L.; Ren, C.Y. Integrating AVHRR and MODIS data to monitor NDVI changes and their relationships with climatic parameters in Northeast China. Int. J. Appl. Earth Obs. 2012, 18, 528-536. [CrossRef]

30. Fay, P.A.; Kaufman, D.M.; Nippert, J.B.; Carlisle, J.D.; Harper, C.W. Changes in grassland ecosystem function due to extreme rainfall events: Implications for responses to climate change. Glob. Chang. Biol. 2008, 14, 1600-1608. [CrossRef]

31. Dong, G.; Guo, J.X.; Chen, J.Q.; Sun, G.; Gao, S.; Hu, L.J.; Wang, Y.L. Effects of Spring Drought on Carbon Sequestration, Evapotranspiration and Water Use Efficiency in the Songnen Meadow Steppe in Northeast China. Ecohydrology 2011, 4, 211-224. [CrossRef]

32. Liu, D.W.; Wang, Z.M.; Song, K.S.; Zhang, B.; Hu, L.J.; Huang, N.; Zhang, S.M.; Luo, L.; Zhang, C.H.; Jiang, G.J. Land use/cover changes and environmental consequences in Songnen Plain, Northeast China. Chin. Geogr. Sci. 2009, 19, 299-305. [CrossRef]

33. Su, H.X.; Feng, J.C.; Axmacher, J.C.; Sang, W.G. Asymmetric warming significantly affects net primary production, but not ecosystem carbon balances of forest and grassland ecosystems in northern China. Sci. Rep. 2015, 5, 9115. [CrossRef] [PubMed]

34. Shen, X.J.; Liu, B.H.; Xue, Z.S.; Jiang, M.; Lu, X.G.; Zhang, Q. Spatiotemporal variation in vegetation spring phenology and its response to climate change in freshwater marshes of Northeast China. Sci. Total Environ. 2019, 666, 1169-1177. [CrossRef] [PubMed]

35. Wang, Z.; Huang, N.; Luo, L.; Li, X.; Ren, C.; Song, K.; Chen, J.M. Shrinkage and fragmentation of marshes in the West Songnen Plain, China, from 1954 to 2008 and its possible causes. Int. J. Appl. Earth Obs. 2011, 13, 477-486. [CrossRef]

36. Wen, B.; Liu, X.; Li, X.; Yang, F.; Li, X. Restoration and rational use of degraded saline reed wetlands: A case study in western Songnen Plain, China. Chin. Geogr. Sci. 2012, 22, 167-177. [CrossRef]

37. Peng, S.S.; Piao, S.L.; Ciais, P.; Myneni, R.B.; Chen, A.P.; Chevallier, F.; Dolman, A.J.; Janssens, I.A.; Penuelas, J.; Zhang, G.X.; et al. Asymmetric effects of daytime and night-time warming on Northern Hemisphere vegetation. Nature 2013, 501, 88-95. [CrossRef]

38. Shen, X.J.; Liu, B.H.; Li, G.D.; Wu, Z.F.; Jin, Y.H.; Yu, P.J.; Zhou, D.W. Spatiotemporal change of diurnal temperature range and its relationship with sunshine duration and precipitation in China. J. Geophys. Res. 2014, 119, 13163-13179. [CrossRef]

39. Qiao, Y.; Liu, H.; Kellomaki, S.; Peltola, H.; Liu, Y.; Dong, B.; Shi, C.; Zhang, H.; Zhang, C.; Gong, J.; et al. Comparison of the effects of symmetric and asymmetric temperature elevation and $\mathrm{CO}_{2}$ enrichment on yield and evapotranspiration of winter wheat (Triticum aestivum L.). Ecol. Evol. 2014, 4, 1994-2003. [CrossRef]

40. Shen, X.J.; Liu, B.H.; Li, G.D.; Zhou, D.W. Impact of Climate Change on Temperate and Alpine Grasslands in China during 1982-2006. Adv. Meteorol. 2015, 2015, 180614. [CrossRef]

41. Dong, Z.; Wang, Z.; Liu, D.; Song, K.; Li, L.; Jiang, M.; Ding, Z. Mapping Wetland Areas Using Landsat-Derived NDVI and LSWI: A Case Study of West Songnen Plain, Northeast China. Int. J. Remote Sens. 2014, 42, 569-576. [CrossRef]

42. Shen, X.J.; Liu, B.H.; Lu, X.G. Weak cooling of cold extremes versus continued warming of hot extremes in China during the recent global surface warming hiatus. J. Geophys. Res. Atmos. 2018, 123, 4073-4087. [CrossRef]

43. Tucker, C.J. Red and photographic infrared linear combinations for monitoring vegetation. Remote Sens. Environ. 1979, 8, 127-150. [CrossRef]

44. Tucker, C.J. Remote-sensing of leaf water-content in the near-infrared. Remote Sens. Environ. 1980, 10, $23-32$. [CrossRef]

45. Shen, X.J.; Liu, B.H.; Henderson, M.; Wang, L.; Wu, Z.F.; Wu, H.T.; Jiang, M.; Lu, X.G. Asymmetric effects of daytime and nighttime warming on spring phenology in the temperate grasslands of China. Agric. For. Meteorol. 2018, 259, 240-249. [CrossRef] 
46. Tucker, C.J.; Slayback, D.A.; Pinzon, J.E.; Los, S.O.; Myneni, R.B.; Taylor, M.G. Higher northern latitude normalized difference vegetation index and growing season trends from 1982 to 1999. Int. J. Biometeorol. 2001, 45, 184-190. [CrossRef]

47. Nemani, R.R.; Keeling, C.D.; Hashimoto, H.; Jolly, W.M.; Piper, S.C.; Tucker, C.J.; Myneni, R.B.; Running, S.W. Climate-driven increases in global terrestrial net primary production from 1982 to 1999. Science 2003, 300, 1560-1563. [CrossRef]

48. Zaitchik, B.F.; Evans, J.P.; Geerken, R.A.; Smith, R.B. Climate and vegetation in the Middle East: Interannual variability and drought feedbacks. J. Clim. 2007, 20, 3924-3941. [CrossRef]

49. Hwang, T.; Band, L.E.; Vose, J.M.; Tague, C. Ecosystem processes at the watershed scale: Hydrologic vegetation gradient as an indicator for lateral hydrologic connectivity of headwater catchments. Water Res. 2012, 48, W06514. [CrossRef]

50. Xing, L.; Niu, Z. Mapping and analyzing China's wetlands using MODIS time series data. Welt. Ecol. Manag. 2019, 27, 693-710. [CrossRef]

51. Zeng, L.; Song, K.; Zhang, B.; Wang, Z.; Du, J. Analysis of evapotranspiration characteristics for different land covers over Songnen Plain based on remote sensing. Trans. Chin. Soc. Agric. Eng. 2010, 26, $233-242$. (In Chinese)

52. Piao, S.; Cui, M.; Chen, A.; Wang, X.; Ciais, P.; Liu, J.; Tang, Y. Altitude and temperature dependence of change in the spring vegetation green-up date from 1982 to 2006 in the Qinghai-Xizang Plateau. Agric. For. Meteorol. 2011, 151, 1599-1608. [CrossRef]

53. Peng, S.; Chen, A.; Xu, L.; Cao, C.; Fang, J.; Myneni, R.B.; Pinzon, J.E.; Tucker, C.J.; Piao, S. Recent change of vegetation growth trend in China. Environ. Res. Lett. 2011, 6, 044027. [CrossRef]

54. Holben, B.N. Characteristic of maximum-value composite images from temporal AVHRR data. Int. J. Remote Sens. 1986, 7, 1417-1434. [CrossRef]

55. Pettorelli, N.; Vik, J.O.; Mysterud, A.; Gaillard, J.M.; Tucker, C.J.; Stenseth, N.C. Using the satellite-derived NDVI to assess ecological responses to environmental change. Trends Ecol. Evol. 2005, 20, 503-510. [CrossRef]

56. Mao, D.H.; Wang, Z.M.; Li, L.; Ma, W. Spatiotemporal dynamics of grassland aboveground net primary productivity and its association with climatic pattern and changes in Northern China. Ecol. Indic. 2014, 41, 40-48. [CrossRef]

57. Yu, H.; Luedeling, E.; Xu, J. Winter and spring warming result in delayed spring phenology on the Tibetan Plateau. Proc. Natl. Acad. Sci. USA 2010, 107, 22151-22156. [CrossRef]

58. Shen, X.J.; Liu, B.H.; Lu, X.G. Effects of land use/land cover on diurnal temperature range in the temperate grassland region of China. Sci. Total Environ. 2017, 575, 1211-1218. [CrossRef]

59. Neubauer, S.C.; Franklin, R.B.; Berrier, D.J. Saltwater intrusion into tidal freshwater marshes alters the biogeochemical processing of organic carbon. Biogeosciences 2013, 10, 8171-8183. [CrossRef]

60. Shen, X.J.; Liu, B.H.; Zhou, D.W.; Lu, X.G. Effect of grassland vegetation on diurnal temperature range in China's temperate grassland region. Ecol. Eng. 2016, 97, 292-296. [CrossRef]

61. Wang, H.B.; Ma, M.G. Impacts of Climate Change and Anthropogenic Activities on the Ecological Restoration of Wetlands in the Arid Regions of China. Energies 2016, 9, 166. [CrossRef]

62. Qiu, X.; Zhang, L.; Wen, L.; Yang, Y.; Tao, P. Studies on changes and cause of the minimum air temperature in Songnen Plain of China during 1961-2010. Acta. Ecol. Sin. 2016, 36, 311-320. [CrossRef]

63. Wang, Y.; Huang, F. Identification and analysis of ecosystem functional types in the west of Songnen Plain, China, based on moderate resolution imaging spectroradiometer data. J. Appl. Remote Sens. 2015, 9, 096096. [CrossRef]

64. Qiu, T.; Jiang, L.L.; Yang, Y. Genetic and epigenetic diversity and structure of Phragmites australis from local habitats of the Songnen Prairie using amplified fragment length polymorphism markers. Genet. Mol. Res. 2016, 15. [CrossRef] [PubMed]

65. Zhang, D.J.; Qi, Q.; Wang, X.; Tong, S.; Lv, X.; An, Y.; Zhu, X. Physiological responses of Carex schmidtii Meinsh to alternating flooding-drought conditions in the Momoge wetland, northeast China. Aquat. Bot. 2019, 153, 33-39. [CrossRef]

66. Wang, D.D.; Wang, Z.Q.; Chen, M.; Zhang, S.Q. Dynamic change of marsh landscape patterns in the west Songnen Plain. Arid Land Geogr. 2006, 29, 94-100. 
67. Qiang, L.; Hong-W., M.A.; Hui, T.; Zhi-X., A.N. Analysis on the distribution change and influencing factors of the wetlands in Songnen Plain. Geol. Resour. 2010, 19, 76-80.

68. $\mathrm{Xu}, \mathrm{Y}$. Complete prohibition of grazing in China's commodity grain base of Songnen Plain. Pratacult. Sci. 2006, 23, 46. (In Chinese)

(c) (

(C) 2020 by the authors. Licensee MDPI, Basel, Switzerland. This article is an open access article distributed under the terms and conditions of the Creative Commons Attribution (CC BY) license (http://creativecommons.org/licenses/by/4.0/). 